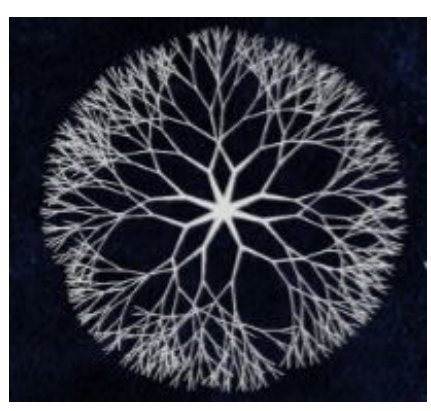

\title{
O Movimento Sanitarista no Brasil: a visão da doença como mal nacional e a saúde como redentora
}

\author{
Luana Tieko Omena Tamano \\ Doutoranda em História Social - FFLCH-USP \\ Bolsista CNPQ \\ luanatamano@yahoo.com.br
}

Recebido em 07/05/2017. Aprovado em 10/08/2017.

Como citar este artigo: Tamano, L. T. O. "O movimento sanitarista no Brasil: a visão da doença como mal nacional e a saúde como redentora”. Khronos, Revista de História da Ciência, nº 4, pp. 102 - 115. 2017. Disponível em < http://revistas.usp.br/khronos $>$. Acesso em dd/mm/aaaa.

Resumo: Pretende-se com este artigo refletir acerca do movimento sanitarista no Brasil no decênio de 1910 por meio de uma análise histórica. Busca-se entender como a ideia de doença foi apresentada, pelos médicos sanitaristas, como um problema central que explicava o "atraso" nacional, o que, por sua vez, realocou a categoria de raça no discurso sobre o futuro do país. Almeja-se, ainda, compreender o que esse movimento significou para a saúde pública nacional, tencionando também demonstrar como os preceitos sanitários foram considerados de grande importância pela elite intelectual e política, resultando em sua propaganda e aplicação.

Palavras-chave: Ciência, História, Higiene, Sanitarismo.

\section{The Sanitary Movement in Brazil: the vision of illness as a "national harm" and health as a redeemer}

\begin{abstract}
The aims of this article is to reflect upon the sanitary movement in Brazilian 1910s decennial, through a historical analysis. It seeks to understand how sanitary doctors presented the idea of illness as a central problem that explained the national "delay". It also crave to understand what this movement meant to the national public health, intending to demonstrate how the sanitary precepts were considered of great importance by intellectual and political elite, resulting in its advertising and application.
\end{abstract}

Keywords: Science, History, Hygiene, Sanitation. 


\section{Introdução}

A ideia de prevenir doenças no Brasil teve seu grande marco inicial com o movimento sanitarista. Na década de 1910, a preocupação passou a ser o interior do país. Até então, a atenção estava direcionada prioritariamente sobre o sanitarismo urbano, com destaque à cidade do Rio de Janeiro e aos portos. O interior passou a ser esmiuçado. Adentrar nesse novo e "desconhecido" ambiente para observar e compreender a sua situação sanitária, buscando soluções, foram metas estabelecidas pelos médicos sanitaristas que embarcaram nessa árdua tarefa.

A realidade encontrada por aqueles médicos desfez a imagem idílica do homem do interior. As imagens românticas da vida interiorana não condiziam em nada com o que viram ao longo de suas viagens. Era urgente mostrar para todo o país a verdadeira situação de vida dessas populações. Por meio de suas falas públicas e das publicações com tais experiências, tornaram seus moradores visíveis para o país, notadamente para os grandes centros urbanos, e, desta feita, chocaram, incomodaram e exigiram medidas que mudassem o panorama encontrado.

Não agradará certamente a franqueza com que expomos a nossa impressão, mas julgamos ser isso um dever de consciência e de patriotismo. É indispensável dizer a verdade embora dolorosa e cruciante e não iludir de forma alguma a nação para que não sofram os jovens de hoje a triste desilusão porque nós passamos quando através dos livros e romances havíamos imaginado um país privilegiado, de terras ubérrimas, matas infindáveis, jazidas auríferas e diamantíferas, inesgotáveis pedras preciosas rolando pelos leitos dos seus rios, povoados seus sertões por uma raça forte e destemida, um paraíso enfim [...] Os sertões que conhecemos, quer os do extremo norte quer os centrais, quer os do norte de Minas são pedaços do purgatório.

Não esmoreça o eminente professor na patriótica campanha iniciada e conte com a colaboração de todos aqueles que não se deixam mais iludir pelas fantasias e devaneios mentirosos de romancistas e poetas, descrevendo os nossos sertões como pedaços de terra da promissão, onde reinam a fartura, a saúde, a alegria, quando ao contrário são eles em geral, a sede da miséria, da doença, da tristeza, do aniquilamento físico e moral do homem [...] vegeta o sertanejo na miséria, idiotado pela moléstia de Chagas, ou cachetizado pela malária ou pela ancilostomíase, inteiramente abandonado à sua trágica sorte, sem assistência de espécie alguma ${ }^{1}$.

${ }^{1}$ PENNA, Belisário Apud SANTOS, Ricardo Augusto dos. Pau que nasce torto nunca se endireita! E quem é bom já nasce feito?: esterilização, saneamento e educação: uma leitura do eugenismo em Renato Kehl (1917-37). 2008. 256 f. Tese (Doutorado em História Social) - Instituto de Ciências Humanas e Filosofia, Universidade Federal Fluminense, Niterói, RJ, 2008, p. 55 e 61. 


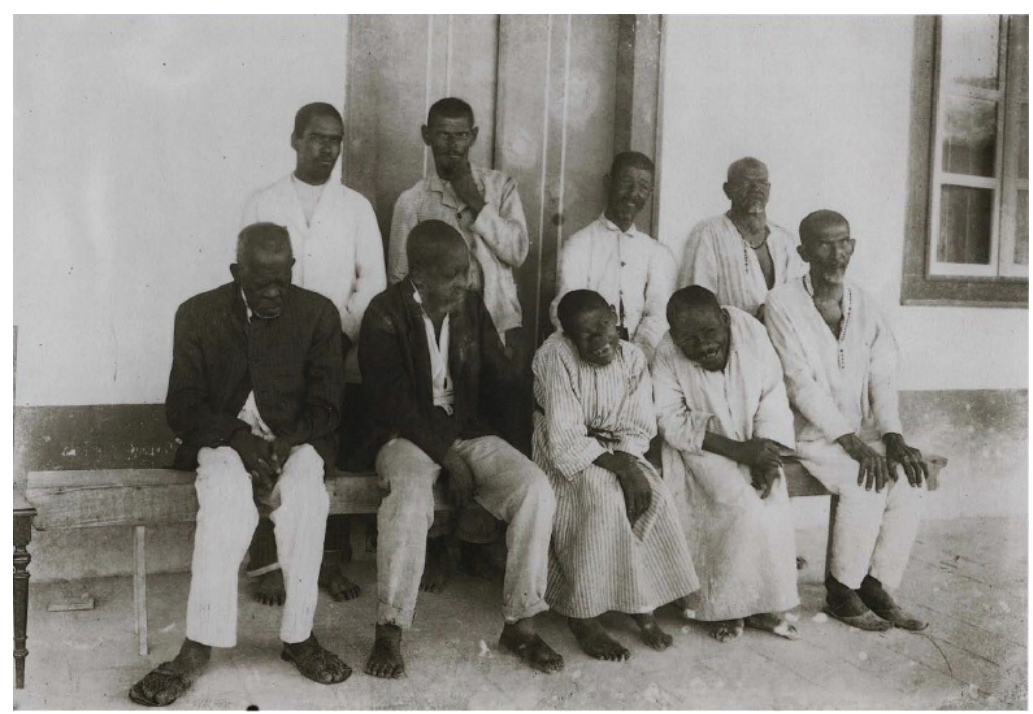

Foto 1. Grupo de doentes de moléstia de Chagas. Asilo de São Francisco (GO), setembro de 1912. In: THIELEN et al, 2002, op., cit., p. 109.

Nesse momento, o ideal nacionalista era forte e a publicação dos relatórios dos médicos, verdadeiros relatórios-denúncias, suscitaram calorosos debates e discussões no plano político, haja vista a incongruência em exaltar o nacional diante da calamidade em que vivia a maior parte da população. Como salientou Hochman, a busca do movimento pela construção da identidade nacional passava também pela construção do poder público, que, por meio dele, integraria todo o país ${ }^{2}$.

\section{As expedições adentram o interior do país}

O contato estabelecido com o interior do país foi realizado com as expedições dos médicos do/enviados pelo Instituto Oswaldo Cruz (IOC) ${ }^{3}$. Desde 1905, o IOC já realizava incursões pelo território nacional, com inspeções sanitárias em portos e campanhas contra doenças, como peste, malária ou febre amarela. Lima assinalou a presença de ações sanitárias, na primeira década do século XX, em 23 portos: na capital maranhense, no interior de São Paulo e Minas Gerais e na Baixada Fluminense ${ }^{4}$. É preciso destacar o fator econômico como grande elemento para a execução e expansão das inspeções sanitárias nos portos brasileiros. O desbravamento

${ }^{2}$ HOCHMAN, Gilberto. A saúde pública em tempos de Capanema: continuidades e inovações. In: BOMENY, Helena (org.). Constelação Capanema: intelectuais e política. Rio de Janeiro; Bragança Paulista, SP: FGV; Edusf, 2001, p. 132.

${ }^{3}$ Em 1900 foi criado o Instituto Soroterápico cujo objetivo era produzir soros e vacinas para a cura da peste bubônica. A intenção era substituir a importação dos soros e vacinas vindos da Europa. A indicação de Oswaldo Cruz (1872-1917) para assumir a chefia da Diretoria Geral de Saúde Pública, em 1903, possibilitou novos rumos para o Instituto, com a construção do prédio de Manguinhos e a expansão da fabricação de produtos biológicos, pesquisas médico-experimentais e ensino da bacteriologia. Em 1907, buscou-se transformar o Instituto Soroterápico em Instituto de Medicina Experimental, com negativas no Congresso. Tal meta foi alcançada no final do mesmo ano, devido, em grande medida, ao prestígio alcançado por Oswaldo Cruz na Exposição de Higiene e Demografia, realizado em Berlim, sendo o Brasil não apenas o único representante americano, como o vencedor do primeiro prêmio. Retornando ao país com glórias, Cruz conseguiu a sanção federal que transformou o Instituto Soroterápico em Instituto de Patologia Experimental, por fim nomeado Instituto Oswaldo Cruz em março de 1908. THIELEN, Eduardo et al. A ciência a caminho da roça: imagens das expedições científicas do Instituto Oswaldo Cruz ao interior do Brasil entre 1911 e 1913. Rio de Janeiro: Fiocruz, 2002, p. 6 a 7.

${ }^{4}$ LIMA, Nísia T. Uma brasiliana médica: o Brasil Central na expedição científica de Arthur Neiva e Belisário Penna e na viagem ao Tocantins de Julio Paternostro. História, Ciência, Saúde - Manguinhos, Rio de Janeiro, v. 16, supl. 1, 2009, p. 232. 
dos sertões atendia a necessidade de comunicação no país que viabilizasse a economia nacional, tal como a construção de linhas férreas e telegráficas. Nesse sentido, Lima afirmou que as "primeiras expedições destinaram-se aos trabalhos profiláticos que acompanharam as ações relacionadas às atividades exportadoras, base da economia do país [... $]^{\prime 5}$.

A expedição de maior destaque na historiografia, devido a sua ampla repercussão pública e pela observação do entorno social, foi a realizada por Belisário Penna (1868-1939) e Arthur Neiva (1880-1943) em 1912. Essa expedição ultrapassou os seus objetivos iniciais. Além de registrarem as condições médico-sanitárias, os médicos analisaram também os aspectos sociais. Seus registros findaram abarcando os aspectos econômicos, alimentares, culturais, dentre outros, daquelas populações.

Esses dois sanitaristas faziam parte da equipe a serviço da Inspetoria das Obras contra a Seca (IOCS), criada em 1909, cujo intuito era o de estudar "as condições meteorológicas, geológicas, topográficas e hidrológicas" da região Nordeste (e o estado de Goiás), bem como "a conservação ou reconstituição das florestas; a construção de estradas de rodagem ou ferrovias e,

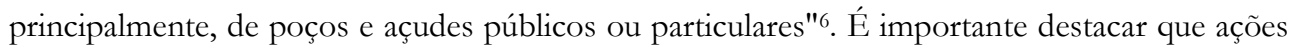
de combate à seca já eram implementadas desde o Império, notadamente a construção de açudes. Nas viagens empreendias sob a tutela do IOCS, no início do século XX, além do IOC, houve a participação do Observatório Nacional e o Serviço Geológico e Mineralógico do Brasil7. Santos afiançou que além dos pesquisadores brasileiros, muitos estudiosos norte-americanos (geólogos, botânicos e topógrafos) foram contratados para atuarem nos levantamentos e estudos no Nordeste $^{8}$.

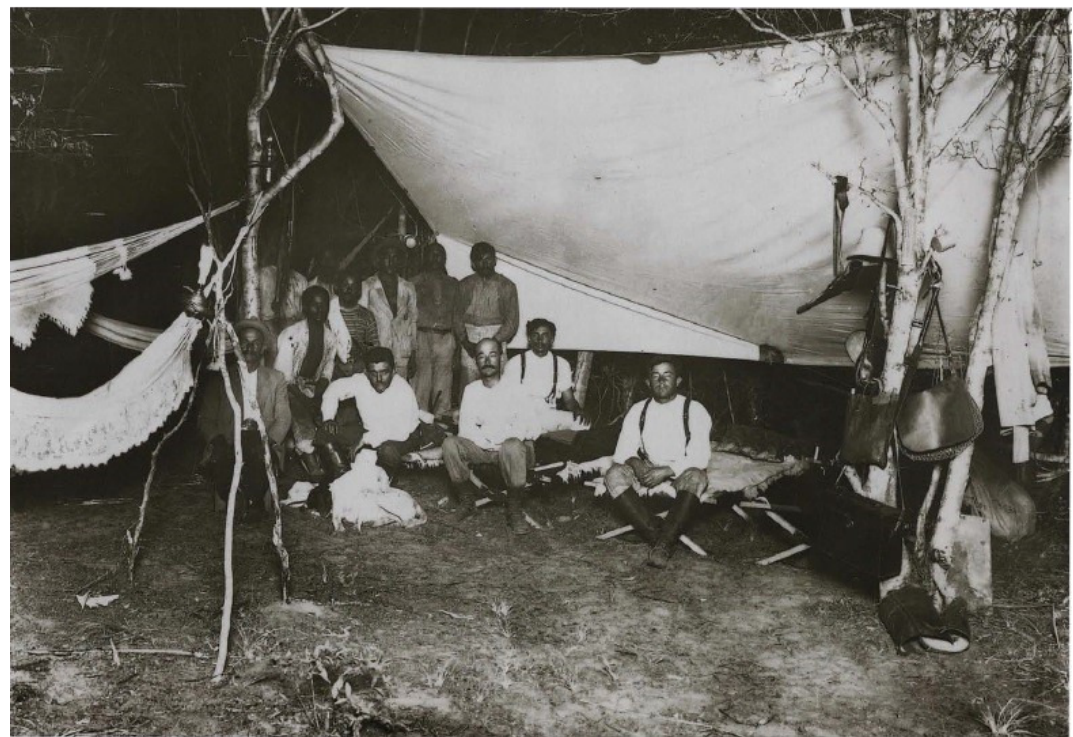

Foto 2. Acampamento. Ao centro, sentados, Belisário Penna e Arthur Neiva. Bebe Mijo (PI), junho de 1912. In: THIELEN et al., 2002, op., cit., p. 97.

O IOC enviou três expedições para atender, em diferentes localidades nordestinas, as determinações da Inspetoria das Obras contra a Seca. Uma liderada por Adolpho Lutz e Astrogildo Machado, no período de abril a julho de 1912, percorrendo o vale do São Francisco, de

5 Ibid., p. 233.

${ }^{6}$ THIELEN et al., 2002, op., cit., p. 53.

7 SANTOS, Cláudia. As comissões cientificas da Inspetoria de Obras contra a seca na gestão de Miguel Arrojado Ribeiro Lisboa (19091912). 2003. 107f. Dissertação (Mestrado em História das Ciências) - Programa de Pós-graduação em História das Ciências da Saúde, Casa de Oswaldo Cruz, Rio de Janeiro, 2003.

8 Ibid., p. 14. 
Pirapora a Juazeiro; outra chefiada por João Pedro de Albuquerque e José Gomes de Farias, de março a julho de 1912, incluindo em seu percurso mais de 15 localidades na travessia dos Estados do Ceará e Piauí; e, por último, aquela comandada por Penna e Neiva, a mais extensa, de março a outubro de 1912, englobando localidades do Norte da Bahia, Piauí e Goiás. As viagens eram longas em duração e trajeto. Nos sertões eram, em boa parte, realizadas em burros e na região Amazônica em barcos. Para efetuá-las, a disposição e disponibilidade eram imprescindíveis àqueles que desejavam atuar como sanitaristas pelo interior do país.

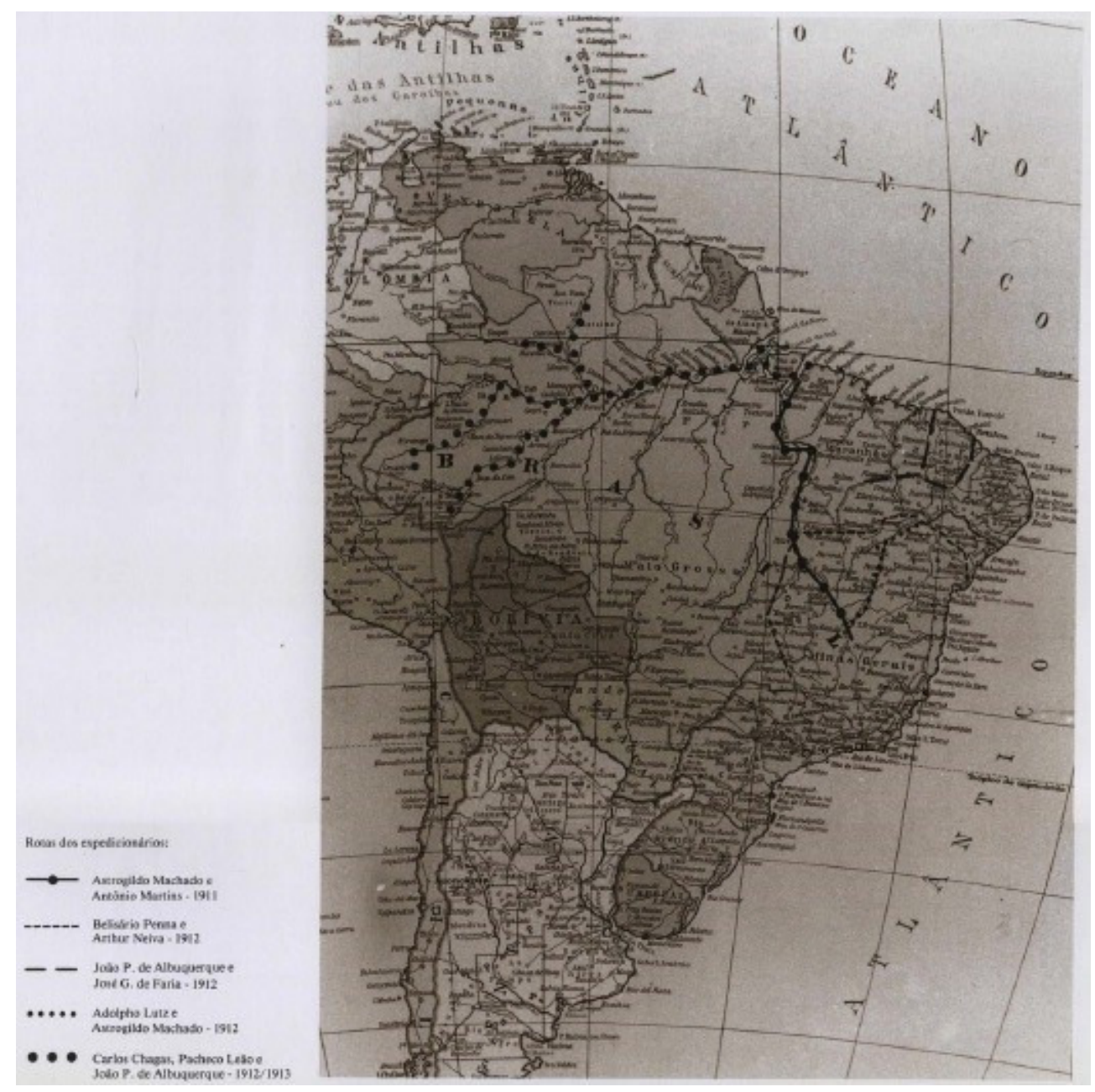

Foto 3. In: THIELEN et al., 2002, op., cit., p. 11.

O descaso público com relação àquelas populações foi uma das abordagens mais destacadas por Penna e Neiva. A situação precária em que viviam (deficiência alimentar, ausência de hospitais, médicos ou remédios, suscetibilidade ao poder local, parcas economias, grande número de enfermos), retratava o abandono do poder público e a dependência dessas pessoas em relação aos mandatários locais. Destarte, os médicos creditavam à presença do Governo Central o poder para mudar tal situação, derivando dessa perspectiva suas certezas quanto a necessidade da centralização da saúde pública. Esse questionamento quanto ao federalismo também se fez presente no âmbito educacional, principalmente na década de 1920, quando algumas reformas 
educacionais foram realizadas em alguns estados do país. Essas iniciativas então isoladas precisavam adquirir um caráter de continuidade ${ }^{9}$. Como enunciou Bomeny, o anseio pela centralização da educação e saúde nacionais, provinha da histórica tradição patrimonial brasileira, que fazia com que os profissionais da saúde e da educação "não conseguissem vislumbrar uma política que não passasse pela unicidade de procedimentos, pela formalização universalizante, o que teve como consequência o processo básico e incontrolável da centralização burocrática"10.

\section{O Estado e a sua responsabilidade pela saúde nacional}

Essas denúncias e críticas ocasionaram uma forte pressão da classe intelectual sobre os políticos e sobre o Governo, desdobrada em mobilização política, da qual a fundação da Liga Pró-Saneamento, em 1918, respondeu enquanto sua materialização. Exigia-se uma atuação enfática, precisa, responsável e eficaz do Governo na profilaxia das endemias rurais que assolavam o país, além da criação de um Ministério exclusivamente dedicado à saúde. No mesmo ano de 1918, houve a proposta da criação de um Ministério da Saúde, empreendida pelo médico e deputado Azevedo Sodré, que, no caso, não chegou a ir para votação. No entanto, nesse ano, houve a reformulação e ampliação dos serviços sanitários federais, a criação do Serviço de Profilaxia Rural e, em 1919, a instituição do Departamento Nacional de Saúde Pública (DNSP). Tais eventos marcaram "um dos raros períodos no século XX em que a saúde ocupou de modo saliente a agenda do Legislativo federal"11.

Apesar do interesse e da luta dos médicos para que a saúde pública entrasse na agenda federal de maneira efetiva, não se pode creditar, como destacou Hochman, aos desejos daqueles, as reformas centralizadoras. Sobretudo, as bases para a centralização da saúde foram negociações políticas. Na concepção daquele autor:

A centralização, em seus aspectos institucionais e mais imediatos, seria resultante de uma dinâmica entre os estados e o poder central - expressa pela tensão centralização/autonomia - mas, também, e fundamentalmente, de uma dinâmica mais horizontal na qual estão em jogo os custos e benefícios da autonomia e da coordenação. Derivou de 'jogos federativos' que se deram, primordialmente, entre estados em posição desigual e não apenas entre estados e o poder federal ${ }^{12}$.

Com o DNSP houve uma reforma na saúde pública brasileira, marcada pela maior capacidade do governo federal em intervir nas localidades do interior do país. A Constituição de 1891 estabelecia, no âmbito da saúde, a autonomia dos estados. À vista disso, era responsabilidade deles a prestação dos serviços de saúde. A proposta de uma centralização, uma nacionalização

\footnotetext{
${ }^{9}$ Vale ressaltar que para os pioneiros da educação nova, que constituíram um movimento por reformas educacionais enfaticamente nos anos de 1930, a interferência do Estado se dava no domínio da coordenação das iniciativas educacionais, como asseverou Xavier, porém, sendo conduzidas por pessoas capazes para tais tarefas. A educação não poderia ser usada para determinados interesses políticos. Ela deveria se manter como campo autônomo. XAVIER, Libânia. O debate em torno da nacionalização do ensino na Era Vargas. Revista Educação, Porto Alegre, v. 30, n. 2, 2005, p. 108.

${ }^{10}$ BOMENY, Helena M. B. Novos talentos, vícios antigos: os renovadores e a política educacional. Estudos Históricos, Rio de Janeiro, v. 06, n. 11, p. 24-39, 1993, p. 27.

${ }^{11}$ HOCHMAN, Gilberto. Saúde Pública e federalismo: desafios da reforma sanitária na Primeira República. In: HOCHMAN, G.; FARIA, C. A. P. de (orgs). Federalismo e Políticas Públicas no Brasil. Rio de Janeiro: Fiocruz, 2013, p. 308.

12 Ibid., p. 305.
} 
da saúde, feria o princípio do federalismo. Os convênios firmados entre os estados e o governo federal "viabilizaram a ação do poder central nos estados, que negociavam suas respectivas autonomias garantidas pela Constituição em troca dos benefícios da ação federal"13.

Os postos de profilaxia de doenças endêmicas nas áreas rurais foram os principais resultados dos acordos estabelecidos entre os estados e o DNSP, os quais eram administrados pelos serviços sanitários federais. Na perspectiva de Hochman, esses convênios constituíram a regra que possibilitou a reforma sanitária na Primeira República, posto que o estabelecimento do convênio dependia da "escolha" dos estados, era voluntário ${ }^{14}$. Por meio de um contrato, os custos com as ações de saúde seriam assumidos pelo governo federal que estabeleceria um prazo para o ressarcimento, ou teria parte dos custos divididos com os estados contratantes no ato do contrato. Ao aceitarem os convênios, esses últimos automaticamente aceitavam sua subordinação, no campo da assistência à saúde, com relação à administração federal.

A fundação do Ministério da Educação e Saúde Pública (MESP), em novembro de 1930, foi realizada em meio a um processo político de grandes transformações. A "revolução" de 1930, abalizada como uma ruptura com o modelo antigo de governo, laureada como a "Nova" República, assinalava, dentro dessa perspectiva do novo, um recomeço da história nacional ${ }^{15}$. Por conseguinte, os governos passados eram vistos como atrasados, fracos, inoperantes, ineficazes, marcados pelo liberalismo e por uma visão eurocêntrica do brasileiro. Uma "Nova" República se construía e determinava, periodizando-se a história do país, um Brasil que não foi. Notadamente o Estado "Novo", em 1937, imprimiria essa ruptura, edificada pelos intelectuais e políticos engajados na concepção de um projeto político, que se consagrava, para eles, como, de fato, moderno e progressista.

O MESP simbolizava os anseios do movimento sanitarista, se não da forma que pensaram, ao menos de maneira parcial. O Ministério teve três diferentes ministros - Francisco Campos (1891-1968), Belisário Penna e Washington Pires (1892-1970) - antes de Gustavo Capanema (1900-1985) assumir sua direção em 1934. Até o final do Governo Provisório (1930-1934) não teve objetivos definidos em sua estrutura administrativa, como asseverou Hochman ${ }^{16}$. As diretrizes de atuação do Ministério só foram, de fato, definidas com a reforma Capanema, em 1937. Com a instauração do estado ditatorial, os ideais de centralização política foram ampliados e efetivados, minando as autonomias estaduais, o que, no âmbito das políticas de saúde pública, significou a concretização dos anseios centralizadores dos sanitaristas ${ }^{17}$.

Ainda que a ideia de centralização do poder esteja ligada à figura de Vargas, não se pode ignorar que mesmo em meio aos mandos locais das oligarquias na Primeira República, houve uma atuação significativa do Estado Central nos demais estados da federação. Os serviços de

13 Ibid., p. 311.

${ }^{14}$ Estes convênios foram firmados pelos estados do Paraná, Minas Gerais e Maranhão, entre 1918 e 1920. Ao final do governo Epitácio Pessoa, em 1922, já eram 15 o número de estados contratantes. Em 1924, passaram a ser 17. Ibid., p. 312.

15 Como avaliou Ângela de Castro Gomes, a polêmica em torno do termo "revolução", no que tange ao seu autêntico caráter revolucionário, enquanto um movimento de transformação das estruturas socioeconômicas, não altera "a centralidade do evento, nem o 'nome' com o qual é identificado, ainda que esse 'nome' não seja muito adequado a 'coisa' que nomeia". GOMES, Ângela de C. Introdução. In: (coord.). História do Brasil nação: 1808-2010. Olhando para dentro: 1930-1964. v. 4. São Paulo; Madrid: Objetiva; Mapfre, 2013, p. 24.

${ }^{16}$ HOCHMAN, Gilberto. Reformas, instituições e políticas de saúde no Brasil (1930-1945). Revista Educar, n. 25,2005 , p. 130.

${ }^{17}$ Sobre o Ministério, a reforma Capanema e a saúde pública no governo Vargas, ver FONSECA, Cristina M. O. Saúde no Governo Vargas (1930-1945): dualidade institucional de um bem público. Rio de Janeiro: Fiocruz, 2007 e HOCHMAN, 2005, op., cit. 
profilaxia espalhados pelo país no final de 1920 atestam isso. A herança do movimento foi absorvida, com reformulações e novas concepções (e uma tomada mais urbana que rural), pelo MESP e àquela geração de sanitaristas deveu-se a luta pela regulamentação da saúde pública, o empenho na formação de profissionais da área, a construção do aparato institucional. Por conseguinte, como destacou Fonseca "o processo de institucionalização da saúde pública que se desenvolve a partir dos anos (19)30 está intimamente entrelaçado à trajetória pessoal e profissional desse grupo de atores"18.

Com a estruturação da saúde no pós-1930, ficou mais evidente a necessidade de profissionais especializados. A preocupação em formá-los data do decênio de 1920, quando "o movimento em prol da profissionalização sanitária deu origem a propostas de criação de escolas e serviços especializados", a exemplo das Escolas de Enfermagens ${ }^{19}$.

\section{A Rockefeller na saúde pública brasileira}

Na condução da formação profissional, a Fundação Rockefeller teve uma participação destacada no Brasil20. Desde 1916, quando desembarcou no país, concedeu bolsas de estudos para os brasileiros na Universidade Johns Hopkins em Baltimore (EUA), influenciando-os e fazendo com que aqueles concretizassem em terras nacionais a sua concepção de saúde pública, baseada "na educação sanitária e na formação de profissionais na área de saúde pública"21. Conforme Faria, tratava-se de uma proposta de intervenção sanitária representada pelos Centros de Saúde (Health Centers), cujo modelo ofertava às visitadoras sanitárias e às enfermeiras papel de destaque. Esse modelo foi adotado pelo Brasil, cujas bases estavam centradas na assistência educativa materno-infantil, atendimento aos tuberculosos, educação sanitária, higiene pré-natal, infantil e rural e análises laboratoriais 22 .

Além de auxiliar na fundação da Escola de Enfermagem Anna Nery, financiou o estudo e erradicação de doenças, auxiliou financeiramente e/ou enviou profissionais para as instituições e cursos nacionais, ofertou bolsas de estudos para brasileiros em importantes instituições no exterior, formou ou especializou médicos brasileiros na Universidade Johns Hopkins, enfatizou a necessidade da pesquisa e dedicação exclusiva dos pesquisadores, entre outras ações. É perceptível que esta Fundação exerceu forte influência para a consolidação da formação da saúde pública no Brasil.

Dentre as ações empreendidas pela Fundação, destaca-se o auxílio prestado à fundação do Laboratório de Higiene em São Paulo, realizada em 1918, por meio do convênio firmado entre aquela e o Estado de São Paulo. O Laboratório veio a funcionar como cadeira na Faculdade de Medicina e Cirurgia de São Paulo até 1924. Neste ano, tornou-se autônomo, passando a de-

${ }^{18}$ FONSECA, Cristina M. O. Trabalhando em saúde pública pelo interior do Brasil: lembranças de uma geração de sanitaristas (1930-1970). Revista Ciência e Saúde Coletiva, Rio de Janeiro, v. 5, n. 2, 2000, p. 395.

19 SANTOS, Luis de Castro; FARIA, Lina. O ensino da saúde pública no Brasil: os primeiros tempos no Rio de Janeiro. Revista Trabalbo, Educação e Saúde. v. 4, n. 2, 2006, p. 292.

${ }^{20}$ Sobre a Fundação Rockefeller no Brasil, ver Os primeiros anos da reforma sanitária no Brasil e a atuação da Fundação Rockefeller (1915-1920). Revista de Saúde Coletiva, Rio de Janeiro, v. 5, n. 1, 1995; SANTOS; FARIA, 2006, op., cit.; KOBAYASHI, Elisabete; FARIA, Lina; COSTA, Maria da C. da. Eugenia e Fundação Rockefeller no Brasil: a saúde como proposta de regeneração nacional. Sociologias, Porto Alegre, ano 11, n. 22, 2009.

${ }^{21}$ FARIA, Lina. Educadoras Sanitárias e Enfermeiras de Saúde Pública: identidades profissionais em construção. Cadernos Pagu, São Paulo, v. 27, 2006, p. 184.

22 Ibid., loc., cit. 
nominar-se Instituto de Higiene, tendo sido transferido oficialmente ao governo do estado, conforme Faria ${ }^{23}$. Essa autonomia foi conquistada sob fortes e severas críticas oposicionistas, como destacou a autora citada. Essas querelas consubstanciavam disputas institucionais e, ao que deixa ver a fala de Faria, de vaidades pessoais ${ }^{24}$.

Uma vez alcançada a autonomia, o Instituto "iniciou um programa de pesquisas independentes" e continuou recebendo o apoio da Rockefeller ${ }^{25}$. Porém, em 1927, e ainda em 1938, sua autonomia voltou a ser questionada e surgiram rumores de que voltasse a ficar subordinado à Faculdade de Medicina ${ }^{26}$. Em 1938, houve a proposta liderada por Sales Gomes, crítico antigo da autonomia e do médico Paula Souza (1889-1951), de unificar os institutos de pesquisas paulistas para que constituíssem "uma única instituição de alto nível científico"27. Tal fato fez com que aquele médico sugerisse que o Instituto fosse incorporado pela Universidade de São Paulo (USP), ficando subordinado à Faculdade de Medicina, novamente. Integrado à USP, por meio do Decreto $n^{\circ}$ 9279, a luta passou a ser "a sua transformação em instituição de ensino superior", buscando-se transformá-lo em Faculdade de Higiene, o que veio a acontecer em 1945. Por fim, em 1969, tornou-se a Faculdade de Saúde Pública ${ }^{28}$.

Ponto essencial para se compreender a atuação da Rockefeller no Brasil diz respeito à forma como seus trabalhos foram desenvolvidos: por meio de parcerias com os médicos e sanitaristas brasileiros. Quando chegaram ao Brasil, os cientistas daquela instituição encontraram uma tradição em pesquisa de certa forma já consolidada, que contava com cientistas muito bem conceituados e de instituições voltadas para o estudo e pesquisa na área da saúde pública, a exemplo da Manguinhos, no Rio de Janeiro, e do Instituto Butantã, em São Paulo. Portanto, suas ações foram realizadas em parceria, com devidas adaptações à conjuntura local, com ênfase ao "modelo centralizado que vinha se implantando no Brasil"29.

A Rockefeller voltou suas atenções para população rural no Brasil e constatou dois fatores específicos que ampliavam o número de doentes no interior do país: a falta de condições sanitárias e o alto índice de analfabetismo e a falta de informação ${ }^{30}$. Tais fatores já havia sido constatados pelos sanitaristas brasileiros, o que impulsionou suas campanhas em prol do saneamento e da educação higiênica. $\mathrm{O}$ analfabetismo era traçado como grande vilão, sendo alvo de campanhas e fervorosos discursos políticos. A questão era tão importante que, em 1915, foi fundada a Liga Brasileira Contra o Analfabetismo. Uma das grandes preocupações da classe in-

${ }^{23}$ FARIA, Lina. O Instituto de Higiene: contribuição à história da ciência e da administração em saúde em São Paulo. Revista Saúde Coletiva, Rio de Janeiro, v. 9, n. 1, 1999, p. 197.

${ }^{24}$ Segundo Faria, o senador Oscar Rodrigues se manifestava contrário aos artigos integrantes do projeto de Paula Souza pela autonomia, por acreditar que funções do Serviço Sanitário seriam atribuídas ao Instituto. Rodrigues Alves, por sua vez, cria que o referido projeto depositaria nas mãos de Souza poderes que esvaziaram os do Serviço Sanitário, além de discordar que o Instituto ficasse responsável pela fiscalização de soros e vacinas, vindo, dessa maneira, a interferir nas atribuições dos Institutos Butantã e Bacteriológico. Houve ainda críticas por parte de Carvalho Lima, na época diretor do Instituto Bacteriológico e do grupo de Francisco Sales de Gomes Júnior, dentro do Serviço Sanitário. No caso desse último, como apresentado pela autora, as críticas contrárias ao projeto de Paula Souza sugeriam um ataque direto à Fundação que havia lhe negado uma bolsa em 1920. Ibid., p. 194 a 195.

25 Ibid., p. 197.

${ }^{26}$ Dentre os que apoiavam a reintegração à Faculdade, esteve o médico sanitarista Arthur Neiva, que havia apoiado a vinda da Rockefeller ao Brasil em 1916, quando era diretor do Serviço Sanitário de São Paulo. Sua desaprovação à autonomia do Instituto, conforme Faria, ocorreu, provavelmente, pela negativa da Fundação em transformar o Instituto Butantã em uma instituição capaz de competir com o IOC na produção e comercialização de soros e vacinas. Ibid., p. 198

${ }^{27}$ Ibid., p. 202.

28 Ibid., p. 203.

${ }^{29}$ FARIA, 1995, op., cit., p. 110.

30 Ibid., p. 124. 
telectual no Brasil dos anos 1920-1930 foi o alcoolismo, então considerando causador de desordens sociais e degeneração. E, em seu combate, o analfabetismo foi igualmente considerado um problema, posto que o meio aventado como o mais eficaz para impedir a proliferação de alcoólicos foi a conscientização. Essa seria alcançada por intermédio da publicidade e da educação. O médico baiano Juliano Moreira (1872-1933) alertou que a enorme quantidade de analfabetos no país consistia um obstáculo considerável. Por esta razão, clamou pela educação do povo e pela necessidade de convencimento das crianças " de que (era) preciso dar combate aos fatores deseugenizantes da espécie, sobretudo o álcool e outros tóxicos [...]"31.

A educação sanitária foi um item de presença importante na agenda da Rockefeller, dos políticos nacionais, dos cientistas, médicos sanitaristas e das várias Ligas criadas no país. Dentre as funções que o Instituto de Higiene deveria cumprir estavam a propaganda e a educação higiênica. As propagandas sanitárias tinham como objetivo "alertar a população sobre a natureza e causa da infecção, modos de transmissão e métodos adequados para a erradicação da doença"32. Essas campanhas também fizeram parte das ações da Liga Brasileira de Higiene Mental ${ }^{33}$.

As publicações em jornais e revistas fortaleciam a transmissão de informações e foram bem utilizadas pelo Instituto. A defesa de uma educação higiênica ganhava, cada vez mais, espaço e adeptos no país. Criou-se uma nova maneira de ver e enfrentar o problema da saúde pública. Com a geração de 1920, o foco deixou de estar centrado em absoluto sobre o estudo e a cura de doenças, para contemplar "a compreensão e superação de problemas sociais"34. A higiene passou então a ser vista como uma aliada para a melhoria da vida das pessoas e como instrumento potente de prevenção de doenças, fossem físicas ou mentais. Como afirmou Wanderbroock Junior, "a higiene ultrapass(ou) os limites dos simples hábitos de limpeza, transformando-se em concepção e ideário" 35. Ela deixou de ser um mero ato, para tornar-se e ser referenciada como uma prática científica, ligada ao bem-estar coletivo, partindo de ações individuais que deviam ser geridas pelos Estados, uma vez que sua ação refletia-se diretamente sobre a saúde pública.

\section{A higiene entra em cena}

${ }^{31}$ MOREIRA, Juliano. Noticiário: A contribuição da higiene mental no $2^{\circ}$ Congresso Brasileiro de Higiene. Arquivos Brasileiros de Higiene Mental, Rio de Janeiro, n. 1, 1925, p. 196 a 197.

32 FARIA, 1999, op., cit., p. 189.

33 A Liga Brasileira de Higiene Mental (LBHM) foi criada pelo médico Gustavo Riedel (1887-1943), em 1922, na cidade do Rio de Janeiro, após, segundo ele, receber de Clifford Beers (1876-1943) a indicação entusiástica para fundar na América do Sul a primeira Associação de Medicina Social. Beers foi um médico norte-americano que, nos idos de 1900, foi internado em alguns sanatórios públicos e particulares para doentes mentais, em virtude de alguns problemas psicológicos que o acometeram. Sua experiência nesses sanatórios resultou na edição de seu livro $A$ mind that found itself, no qual se opôs e criticou os tratamentos realizados naquelas casas. A partir de sua experiência, lançou as bases do movimento da higiene mental, cujo objetivo foi modificar a forma como o doente mental era visto e tratado, possibilitando uma assistência condigna. Além disso, buscou prevenir a eclosão das doenças mentais. Seu trabalho foi a base para a higiene mental enquanto proposta para a melhoria da assistência aos alienados. Em 1909 ele criou o Comitê Nacional de Higiene Mental, cuja proposta foi disseminada mundo afora nas fundações de Ligas/Sociedades de Higiene Mental. A Liga congregou uma grande quantidade de médicos, sobretudo, porém não somente esses profissionais, sendo um espaço destinado a discussão e ações concretas de eugenia e higiene mental no país. Sobre a LBHM e seus trabalhos realizados no país ver REIS, José R. F. Higiene mental e engenia: o projeto de "regeneração nacional" da Liga Brasileira de Higiene Mental (19201930). 1994. 353f. Dissertação (Mestrado em História) - Instituto de Filosofia e Ciências Humanas, Universidade de Campinas, Campinas, SP, 1994 e os artigos dos Arquivos Brasileiros de Higiene Mental, revista oficial daquela congregação.

34 SANTOS; FARIA, 2006, op., cit., p. 294.

35 WANDERBROOCK Jr. Durval. A educaşão sob medida: os testes psicológicos e o higienismo no Brasil (19141945). 2007. 178f. Dissertação (Mestrado em Educação) - Faculdade de Educação, Universidade Estadual de Maringá. Paraná, 2007, p. 18. 
Ao compreender que a higiene era uma necessidade para o desenvolvimento nacional, sua prática penetrou vários âmbitos da vida humana: na gestação - higiene da espécie; na infância - higiene infantil; na escola - higiene escolar; na profissão - higiene do trabalho; no indivíduo higiene corporal; na moradia - higiene urbana e sanitária; com as doenças - higiene profilática ${ }^{36}$. A mente também foi higienizada. Como asseverou o médico alagoano Arthur Ramos (19031949), a higiene mental seria uma parte da medicina do futuro, que "previne a doença, forma funcionários da saúde, em vez de médicos-funcionários da doença" ${ }^{37}$. Antecipar a doença, prevenindo-a, e focar na formação daqueles que podiam impedir sua ação no corpo e na mente, foram alguns dos objetivos da higiene mental, pressupondo que o não cuidado com a mente levaria ao crime, às neuroses e psicoses, fatigava o corpo e minava o desenvolvimento do indivíduo e, por conseguinte, da nação.

Dessa maneira, a higiene precisava estar em consonância com a vida cotidiana e deveria fazer parte dos hábitos de todos. O seu raio de ação deveria ser ampliado. Antes a política de saúde pública estava alicerçada sobre a cura da doença. Com o tempo, percebeu-se que tal postura não bastava. Novas práticas surgiram e passaram a ser usadas, como a educação higiênica, muitas vezes imposta.

Em artigo dedicado à análise da educação higiênica, na visão ótica de Belisário Penna, Santos abordou como os preceitos higiênicos foram impostos às populações pobres da cidade do Rio de Janeiro ${ }^{38}$. O autor apresentou em seu texto um relatório, de 1905, apresentado por Penna, na ocasião inspetor sanitário, a Oswaldo Cruz, então dirigente da Diretoria Geral de Saúde Pública, no qual aquele inspetor transcreveu as "práticas educativas e/ou coercitivas que os inspetores utilizavam para obter os objetivos". Santos destacou os modos persuasivos utilizados por Penna para cumprir o código sanitário, como ameaças de prender os oposicionistas em hospitais ou multas aos que não cumprissem as profilaxias higiênicas ${ }^{39}$. No entanto, em uma passagem mais adiante, ele afirma que "o uso da força cedia espaço para que a educação e a higiene não se impusessem repressivamente, mas por meio de práticas de convencimento"40. Dentro do projeto de nação que se forjava, era preciso que hábitos de higiene se tornassem rotina. As ações descritas por Penna demonstram que os preceitos higiênicos foram, de fato, impostos de maneira invasiva. Mesmo que a educação fosse vista como um meio menos invasivo de impor certas práticas, ela apenas atenuava a forma como impô-las.

A educação foi pensada por Penna, e muitos outros de sua época, como elemento capaz de criar uma consciência higiênica. Ser um país civilizado e moderno era, necessariamente, ser composto por indivíduos sadios e fortes. Porém, essa educação, como ressaltou o sanitarista, não estava limitada a ler e escrever, incluindo também a convicção "de que deve construir a sua habitação de acordo com os preceitos da higiene, quando aprender a alimentar-se, a beber água

36 Ibid., p. 20.

${ }^{37}$ RAMOS, Arthur. Saúde do espírito. $6^{\circ}$ ed. Rio de Janeiro: Ministério da Saúde/Serviço Nacional de Educação Sanitária, 1955, p. 07.

38 Penna foi nomeado inspetor sanitário em maio de 1904 e dentre as áreas de sua responsabilidade estava compreendida uma "zona de pequeno comércio e inúmeros cortiços". SANTOS, Ricardo dos. O plano de educação higiênica de Belisário Penna 1900-1930. Revista Dynamis, v. 32, n. 1, 2012, p. 55.

39 Afirmou Penna a esse respeito: "O inspetor é quem está em contato direto e imediato com a população; quem executa o regulamento; quem aplica penas; quem atende em primeiro lugar as reclamações, cabe a maior responsabilidade na execução da lei, que é benéfica em seus efeitos, mas dura na aplicação. O povo, em geral, tem aversão à remoção para hospitais de isolamento, e esse sentimento, aliás injustificável e filho apenas da sua ignorância absoluta em matéria de higiene, foi um elemento por mim aproveitado para conseguir vacinações (....) O povo, em geral, é obediente e submisso, aceitando os conselhos e determinaçoes da autoridade sanitária, que vai cumprindo sem grande dificuldade o regulamento sanitário, notando eu com grande satisfação que as condições sanitárias melhoraram sensivelmente" Ibid., p. 56, grifos nossos.

40 Ibid., p. 59. 
limpa, a defender-se de insetos e parasitas transmissores e causadores de doenças, quando se dispuser à prática das virtudes higiênicas do asseio e da sobriedade"41.

Nesse mesmo relatório, o sanitarista mineiro relatou as dificuldades encontradas para executar as suas funções, enquanto inspetor sanitário. Tais dificuldades provinham da resistência popular às medidas profiláticas delineadas pelo governo. Os preceitos higiênicos eram validados pela ciência médica e sua aplicação era vista como uma necessidade pelo bem comum. A imposição foi, via de regra, a forma utilizada para a aplicação de tais preceitos, uma vez que o povo era visto e tratado como massa ignorante (e foco de doenças) e o saber médico como inquestionável. Mas a realidade não se deu neste plano. As reações populares se apresentaram sob variadas formas: recusa de recebimento em suas casas (incluindo pedidos jurídicos de habeas corpus), negativa de aplicação, a expulsão dos representantes do governo de suas áreas de convivência ${ }^{42}$. Para aplicar tais medidas, o auxílio policial era requisitado e sua presença era mais um agravante para a negativa às ações médico-sanitárias.

Quando abordou o trabalho desenvolvido pelos sanitaristas da década de 1930 a 1970, Cristina Fonseca relatou a entrada desses médicos no espaço privado ${ }^{43}$. A campanha contra a febre amarela, liderada pela Fundação Rockefeller na década de 1930, tinha a visita familiar como um dos destaques do serviço a ser realizado. Para realizar a viscerotomia, os médicos adentravam em um espaço muito particular da família, pois sua ação se dava no exame do indivíduo morto, cuja morte estava possivelmente ligada à doença ${ }^{44}$. A esses médicos era permitido inspecionar as casas, incluindo o controle do sepultamento ${ }^{45}$. Para conseguirem efetuar o trabalho, os médicos se cercavam de pessoas da própria localidade. Exumar um cadáver era violar crenças. Porém, em função do coletivo era não só necessário como também permitido legalmente. Esses fatos evidenciam como as práticas médicas foram realizadas de maneira agressiva, apoderando-se de um saber e poder para ser impostas.

O projeto de educação higiênica proposto por Belisário Penna contemplava, com ênfase, o controle dos hábitos sociais. Para ele, "a educação higiênica orientaria a constituição de uma ordem social, a qual presidiria a higiene das escolas, lares e cidades"46. Fica perceptível que o intuito de modelar a população, forçando o aprendizado e práticas de novos hábitos, modificando suas vidas e interferindo diretamente sobre suas relações e convivências, era um ideal disseminando entre aqueles que pensavam o destino e a salvação da nação. Um ideal que fazia parte da época e que, ainda que pudesse haver vozes dissonantes, prevalecia. A educação como meio para aplicar tais preceitos era defendida por muitos.

As investidas médicas obtiveram vitórias e fracassos. A resistência foi um fator preponderante para que algumas ações e projetos fossem inviabilizados. No entanto, muitas outras ações foram possíveis e concretizadas, contando, inclusive, com a violência para serem efetivadas. Ainda que laureado pelo status da ciência, o saber médico não se pôs de forma inquestionável ao povo, embora forçasse sua condição de verdade absoluta. O alvo das políticas médicas era,

\footnotetext{
${ }^{41}$ Ibid., p. 57.

42 Mota e Santos analisando a resistência popular na cidade de São Paulo, abordaram o caso de Astolpho Ferreira de Oliveira que, em 1905, tentou obter habeas corpus para impedir a entrada de agentes sanitários em sua casa, por se sentir "ameaçado de sofrer constrangimento ilegal por ter sido intimado pelo inspetor sanitário Dr. Alvaro Motta para frequentar a entrada de sua casa". Seu pedido foi negado, pois a ação visava um bem coletivo e "a ninguém é lícito fazer de sua casa um foco epidêmico, pondo em perigo de vida os que nela habitam e a outrem". MOTA, André; SANTOS, Marco. Entre algemas e vacinas: medicina, polícia e resistência popular na cidade de São Paulo (1890-1920). Revista Novos Estudos, n. 65, 2003, p. 164.

43 FONSECA, 2000, op., cit.

${ }^{44}$ A viscerotomia consistia na excisão, parcial ou total, das vísceras de cadáveres para exames.

${ }^{45}$ FONSECA, 2000, op., cit., p. 396.

46 SANTOS, R., 2012, op., cit. p. 60.
} 
majoritariamente, as classes menos favorecidas. Todavia, é preciso salientar que as regras sanitárias foram empregadas não apenas aos economicamente desfavorecidos, mas também aos indivíduos abastados, fosse no âmbito rural, com os coronéis que deveriam não só permitir inspeções sanitárias em suas propriedades, como também estavam sujeitos a uma legislação, fosse na esfera urbana, com os donos de hospedarias, que muitas vezes pertenciam a políticos ou industriais.

Na crônica Os médicos e o espirita, de 1921, Lima Barreto (1881-1922) destacou a figura do médico que se apresentava como o detentor de uma verdade maior e suas ações de interferência sobre a vida dos outros ao se arrogar "o direito de dirigir os engenheiros encarregados de obras de saneamento, de dirigir os políticos no governo dos povos, de substituir as mães no acalentar dos filhos $[\ldots]^{47}$. Com relação à maneira como aplicariam "suas severas e infalíveis teorias", Barreto chamou a atenção para a diferença quando para os "fartos, especialmente médicos notáveis" e quando para "os demais, principalmente os miseráveis", sendo vexatória e brutal aos segundos, ao passo que aos primeiros "não h(avia) necessidade de energias despóticas"48. O ponto de vista de Lima Barreto pode ser interpretado como um dos lados da discussão e apreensão sobre a medicina, suas descobertas e as maneiras como se efetivavam.

\section{Conclusão}

No projeto de nação concebido pelos médicos, intelectuais e políticos, respaldado sobre um imaginário moderno para o país, "a questão fundamental era [...] adequar esta modernidade a um quadro institucional possível". Era preciso e urgente resolver problemas herdados do Império, somados àqueles advindos com a instauração da República, orquestrando uma modernidade, na qual tinha-se que trabalhar com "o moderno que se imp(unha) e os privilégios imperiais de que não se que(ria) abrir mão". Na instalação dos novos modelos sociais, fortemente alicerçados sobre uma normatização social, os intelectuais nacionais, com forte apelo aos médicos, mas também aos engenheiros e educadores, ficaram com a incumbência (ou se incumbiram?!) de criar o Brasil moderno ${ }^{49}$.

Nesse projeto, questões como raça e miscigenação foram acionadas ao se pensar o país e as projeções futuras, e não poderia ser diferente. Desde o século XIX o debate em torno da categoria de raça e da prática da miscigenação foi extenso no país, e, como visto acima, desde então, as inquietações da classe intelectual giravam em torno do que fazer com o país, naquela altura já composto por um enorme contingente de mestiços. O movimento sanitarista esboçou mudanças interpretativas acerca do "atraso" nacional, propondo novas maneiras de ver e ler a história do país. A figura emblemática do Jeca Tatu de Monteiro Lobato (1882-1948) simbolizava a regeneração.

Sempre presente em análises sobre o movimento sanitarista no Brasil ou do período em apreço, o Jeca Tatu representa a mudança pessoal de um indivíduo degenerado, totalmente esgotado, em um ser forte e empreendedor. O texto foi originalmente publicado no O Estado de São Paulo e reunido com outros textos no livro Problema Vital. O título - "Ressurreição" - já evidencia os propósitos do autor. A caracterização do Jeca é a de um homem que "passava os dias de cócoras, pitando enormes cigarrões de palha, sem ânimo de fazer coisa nenhuma", um

47 BARRETO, Lima. O médico e o espírita. In:__ Toda crônica. Organização de Beatriz Rezende e Rachel Valença. v. I. Rio de Janeiro: Agir, 2004, p. 334.

48 Ibid., p. 335.

${ }^{49}$ HERSCHMANN, Micael; PEREIRA, Carlos. O imaginário moderno no Brasil. In: (org.). $A$ invenção do Brasil moderno: medicina, educação e engenharia nos anos 20-30. Rio de Janeiro: Rocco, 1994, p. 12 e 21. 
"gravíssimo preguiçoso".... "além de vadio, bêbado". Com o diagnóstico de que, na verdade, sofria de ancilostomíase, conforme o "Dotô", realizou o tratamento receitado e ressurgiu. Confiou na ciência, tomou remédios, passou a usar botina e não bebia mais (atentar para o conselho de não ingerir álcool, uma frente defendida pelo movimento, pelas ligas de higiene e pela eugenia). O caso do Jeca não podia ser uma exceção. A própria personagem se conscientiza de que precisa - é seu dever - passar adiante os conhecimentos adquiridos: "O meu patriotismo é este. Minha divisa: curar gente. Abaixo a bicharia que devora o brasileiro". Ao final do texto, Lobato incita um conselho aos leitores. Não qualquer leitor, mais os meninos que "nunca se esqueçam desta história; e, quando cresceram, tratem de imitar o Jeca". Afinal, tal postura era um dever patriótico e um ganho financeiro, posto que veriam "o trabalho dessa gente produzir três vezes mais" 50 .

Com um grande contingente de mestiços, o Brasil vivia as angústias de se fazer uma nação civilizada e moderna em meio a prognósticos extremamente negativos no que dizia respeito à miscigenação. Como visto, com o movimento sanitarista a visão sobre a raça, enquanto responsável pelas mazelas nacionais, foi "transferida" para as doenças. Isso não quer dizer, de forma alguma, que o fator racial deixou de ser considerado ou que não continuasse a ser reputado como um entrave - grave e grande - ao desenvolvimento do país. Os sanitaristas Arthur Neiva e Belisário Penna afirmaram em seu Cadernos de Viagem, que "seriam o governo e a doença e não mais a natureza, a raça ou o próprio indivíduo, os grandes culpados pelo abandono da população à sua própria sorte" 51 . Esta nova perspectiva de leitura aventada pelos dois sanitaristas citados situou o poder público no cerne do problema, cobrando programas e soluções.

As doenças passaram a figurar como um grande causador do flagelo do homem brasileiro, fosse no interior, fosse nos centros urbanos. Essa nova chave explicativa (doença/saúde) possibilitava uma recuperação, permitia uma saída. Ao que era degenerado, poder-se-ia regenerar, por intermédio de medidas profiláticas, controles sanitários, campanhas e educação higiênica. Obviamente que quanto a esse aspecto havia discordâncias, pois não se pode pensar nesta chave "redentora" como uma ideia homogênea, mas, sem dúvida, vislumbrada por muitos pensadores da época como um instrumento salvacionista ou, ao menos, atenuante.

${ }^{50}$ LOBATO, Monteiro. Problema vital, Jeca Tatu e outros textos. São Paulo: Globo, 2010, p. 102 a 111.

${ }^{51}$ LIMA, Nísia Trindade; HOCHMAN, Gilberto. Pouca saúde e muita saúva: sanitarismo, interpretações do país e ciências sociais. In: HOCHMAN, Gilberto; ARMUS, Diego (orgs.). Cuidar, Controlar, Curar. ensaios históricos sobre saúde e doença na América Latina e Caribe. Rio de Janeiro: Fiocruz, 2004, p. 501. 